\title{
The Financial Risk Research of E-Commerce Enterprise Base on Harvard Analytical Framework --Taking Alibaba as an Example
}

\author{
Feng Yahong ${ }^{1, a}$, Cao Feng ${ }^{1, b, *}$ \\ 'Xi'an University of Science and Technology, Xi'an \\ a2437578442@qq.com, b67567807qq.com,
}

Key words: Financial risk; Harvard analysis framework; Alibaba; F score model

\begin{abstract}
In order to explore the e-commerce enterprises currently exist in the main financial risks,this article to Alibaba as an example, using Harvard analysis framework, from the strategic, accounting, financial and prospects of the level of analysis. The research shows, alibaba's main financial risk exists with internal strategic decision-making risk, main business single risk, credit recovery risk, then give risk prevention advice, and it is expected to provide reference for the financial risk identification and management of e-commerce enterprises.
\end{abstract}

\section{Introduction}

E-commerce enterprises in which the environment is increasingly complex and changeable, financial risk is currently the majority of electricity business enterprises are facing one of the major risks, but also the future development of e-commerce enterprises the most important obstacles. Therefore, it is necessary to carry out systematic research on the financial risk of e-commerce enterprises.Jeffrey Erayporth(2009) from the perspective of monetary fund and argues that financial capital and investment decisions are related to the financial risks of e-commerce enterprises ${ }^{[1]}$. Gai \& Kapadia (2010) analyzes the relationship between dynamic financial markets, financial risk expansion and Internet of development, and illustrates the impetus of this relationship to the ebusiness operations and the unavoidable risks ${ }^{[2]}$. Feng Gaofei (2016) analyzes the financial risks in the context of Suningyun and Alibaba strategic alliances, and puts forward the specific opinions on the strategic alliance of domestic electric business enterprises ${ }^{[3]}$. Xu Yufang (2017)selected 20 listed financial business data of listed e-commerce as a sample, through the F score analysis model of e-commerce business $\mathrm{M} \& \mathrm{~A}$ risk ${ }^{[4]}$.

Based on the Harvard analysis framework ${ }^{[5]}$, this paper from its environment and financial data, identifies and analyzes the financial risk of the company and puts forward some suggestions to provide reference for the financial risk management of e-commerce enterprises.

\section{Alibaba case analysis}

\subsection{Strategic analysis}

Strategic analysis is to assess the macro environment of the enterprise and to develop an internal strategic plan to better improve the profitability of the enterprise.

\subsubsection{Macro - environmental changes}

First of all, in the economic environment, in recent years, China's economic slowdown, consumer disposable income has been limited, consumer goods market growth slowed. Second, in the social environment, China's current urbanization rate has more than $50 \%$, income distribution reform, the middle class-based consumer groups in the rapid formation and expansion. Finally, in the technical environment, the Internet technology and the vigorous development of logistics, making a huge change in consumer behavior, the application of new technologies may affect the development of Alibaba.

\subsubsection{Internal strategic decision}

At this stage Alibaba's overall strategy is to establish a world, open, cooperation the marketization, systematic and informative electricity business ecosystem. Alibaba business capacity and 
profitability continues to increase, the amount of financing will also continue to increase. Therefore, when the management of investment and financing unreasonable, decision-making mistakes, Alibaba there is the risk of internal strategic decision-making mistakes.

\subsection{Accounting analysis}

\subsubsection{Main business structure}

By Table 1, Alibaba's main source of revenue is its core business, 2012-2016 annual report shows that core business accounted for more than $90 \%$, cloud computing and Internet infrastructure, other business and less than $10 \%$ of all income, This shows that Alibaba is the main business of a single risk. With the continuous innovation of science and technology, if the core business is replaced, then Alibaba will be a crisis of survival,is one of the risks facing Alibaba.

Table 1 Alibaba main business structure table

\begin{tabular}{cccccc}
\hline & $\begin{array}{c}2016 \text { annual } \\
\text { report }\end{array}$ & $\begin{array}{c}\text { 2015annua } \\
\text { 1 report }\end{array}$ & $\begin{array}{c}2014 \text { annual } \\
\text { report }\end{array}$ & $\begin{array}{c}2013 \text { annual } \\
\text { report }\end{array}$ & 2012annual report \\
\hline Operating income & $15,827,300$ & $10,114,300$ & $7,620,400$ & $5,250,400$ & $3,451,700$ \\
\hline Core business & $13,388,000$ & $9,195,000$ & $6,942,300$ & $4,998,300$ & $3,332,700$ \\
\hline $\begin{array}{c}\text { Cloud computing and } \\
\text { Internet infrastructure }\end{array}$ & 666,300 & 301,900 & 127,100 & 77,300 & 65,000 \\
\hline $\begin{array}{c}\text { Digital media and } \\
\text { entertainment }\end{array}$ & $1,473,300$ & - & - & - & - \\
\hline Other business & 299,700 & 617,400 & 551,000 & 174,800 & 54,000 \\
\hline Operating cost & $5,948,300$ & $3,435,500$ & $2,383,400$ & $1,336,900$ & 971,900 \\
\hline gross profit & $9,879,000$ & $6,678,800$ & $5,237,000$ & $3,913,500$ & $2,479,800$ \\
\hline Gross margin $(\%)$ & 62.42 & 66.03 & 68.72 & 74.54 & 71.84 \\
\hline Data sour
\end{tabular}

Data source: Wind database

\subsubsection{Accounts receivable}

From Table 2, the accounts receivable in 2012-2016 continued to rise. Other receivables in 2016 reached 2,035,000 million, an increase of 1,082.8 million over 2014, showing that Alibaba credit business development speed, is expected to future accounts receivable amount will continue to grow. Due to 2016 Alipay real name users reached 400 million, assuming $0.01 \%$ of the users each occurred 1,000 bad debts, bad debts will be as high as 45 million, the higher the risk of credit recovery.

Table 2 Alibaba Accounts Receivable Table

\begin{tabular}{lccccc}
\hline & $\begin{array}{c}2016 \\
\text { annual report }\end{array}$ & $\begin{array}{c}2015 \text { annual } \\
\text { report }\end{array}$ & $\begin{array}{c}2014 \text { annual } \\
\text { report }\end{array}$ & $\begin{array}{c}2013 \text { annual } \\
\text { report }\end{array}$ & $\begin{array}{c}2012 \\
\text { Annual report }\end{array}$ \\
\hline Total receivables & $2,437,800$ & $1,302,500$ & $1,058,900$ & 317,500 & 52,100 \\
\hline $\begin{array}{l}\text { Accounts receivable } \\
\text { and notes }\end{array}$ & 438,800 & 120,900 & 106,700 & 26,900 & 13,500 \\
\hline Other receivables & $2,035,000$ & $1,181,600$ & 952,200 & 290,600 & 38,600 \\
\hline
\end{tabular}

Data source: Wind database

\subsection{Financial analysis}

\subsubsection{Risk of debt service}

From Table 3, Alibaba's asset-liability ratio decreased from $74.54 \%$ in 2012 to $31.4 \%$ in 2015 and $36.05 \%$ in 2016, indicating that Alibaba's total liabilities continued to decrease and the solvency was improved,which reflects the lower risk of Alibaba debt. 
Table 3 Alibaba solvency chart

\begin{tabular}{cccccc}
\hline & 2016 annual report & 2015 annual report & $\begin{array}{c}2014 \text { annual } \\
\text { report }\end{array}$ & $\begin{array}{c}2013 \text { annual } \\
\text { report }\end{array}$ & 2012 annual report \\
\hline total indebtedness & $18,269,100$ & $11,456,100$ & $9,736,300$ & $7,073,100$ & $4,754,900$ \\
\hline total assets & $50,681,200$ & $36,445,000$ & $25,543,400$ & $11,154,900$ & $6,378,600$ \\
\hline $\begin{array}{c}\text { asset-liability ratio } \\
(\%)\end{array}$ & 36.05 & 31.43 & 38.12 & 63.41 & 74.54 \\
\hline current assets & $18,251,600$ & $13,407,000$ & $14,210,900$ & $6,783,300$ & $4,316,200$ \\
\hline Current liabilities & $9,377,100$ & $5,203,900$ & $3,967,200$ & $3,738,400$ & $2,399,500$ \\
\hline current ratio & 1.95 & 2.58 & 3.58 & 1.81 & 1.80 \\
\hline
\end{tabular}

Data source: Wind database

\subsubsection{Operating risk}

From Table 4, Jingdong, Amazon total assets turnover rate is high, basically more than 1. 8, compared to representative competitive enterprises, Alibaba's total asset turnover rate of the lowest, basically below 0.5 , indicating his total assets turnover Slow, productivity is not strong.Alibaba can be seen on the plant, equipment and other low utilization of fixed assets, which will reduce the profitability of enterprises, there is operational risk.

Table 4 Comparison of the total assets turnover rate

\begin{tabular}{ccccc}
\hline & 2016 annual report & 2015 annual report & $\begin{array}{c}2014 \text { annual } \\
\text { report }\end{array}$ & $\begin{array}{c}\text { 2013annual } \\
\text { report }\end{array}$ \\
\hline Alibaba & 0.36 & 0.33 & 0.42 & 0.60 \\
\hline Pcln & 0.57 & 0.57 & 0.67 & 0.80 \\
\hline Amazon & 1.83 & 1.78 & 1.88 & 2.05 \\
\hline JD & 2.12 & 2.39 & 2.49 & 3.16 \\
\hline
\end{tabular}

Data source: Wind database

\subsection{Prospect analysis}

The foreground analysis can comprehensively use the tools of statistics and econometrics to scientifically predict the future of the enterprise and play an important role in guiding the development of the enterprise.

According to the study of $\mathrm{Xu}$ Yufang ${ }^{[4]}$, while the F-score model predicts the result is more timely and its reliability is higher. Therefore, this study will use F fractional model to analyze the financial risk of e-commerce enterprises.

$F$ fractional model is as follows:

$\mathrm{F}=-0.1774+1.1091 \mathrm{X} 1+0.1074 \mathrm{X} 2+1.9271 \mathrm{X} 3+0.0302 \mathrm{X} 4+0.4961 \mathrm{X} 5$

Judgment criteria: $\mathrm{F}<0.0274$, bankruptcy area; F>0.0274, safe area

According to the model, from 2013 to 2016 Alibaba's financial data for its financial early warning forecast.

Table 5 F Fractional model for Alibaba's financial risk outlook forecast

\begin{tabular}{ccccc}
\hline & 2016 year & 2015 year & 2014 year & 2013 year \\
\hline $\mathrm{X} 1 * 1.1091$ & 0.1942 & 0.2496 & 0.4448 & 0.3027 \\
\hline $\mathrm{X} 2 * 0.1074$ & 0.0023 & 0.0023 & 0.0010 & 0.0001 \\
\hline $\mathrm{X} 3 * 1.9271$ & 0.5345 & 1.2996 & 0.5563 & 0.7597 \\
\hline $\mathrm{X} 4 * 0.0302$ & 0.0536 & 0.0659 & 0.0490 & 0.0174 \\
\hline $\mathrm{X} 5 * 0.4961$ & 0.0537 & 0.1949 & 0.0837 & 0.1288 \\
\hline-0.1774 & - & - & 0.9574 & - \\
\hline $\mathrm{F}$ & 0.6609 & 1.6349 & $-7.17 \%$ & - \\
\hline $\begin{array}{c}\text { F Change } \\
\text { situation }\end{array}$ & $-59.58 \%$ & $70.76 \%$ & Safety & Safety
\end{tabular}

Data source: Wind database 
From the table 5, Alibaba's financial risk forecast is in the safe area, the development prospect is good.

\section{3 .Conclusions and Suggestions}

This paper finds that the higher financial risk at the present stage includes the risk of internal strategic decision-making mistakes, The main business risk, the risk of credit recovery. Ecommerce enterprises in the follow-up to avoid financial risks in the process,Focus on the following aspects of work.

\subsection{Establish a sound internal strategic decision-making and supervision mechanism}

E-commerce enterprises should be combined with the macro environment, make full use of internal audit techniques and procedures to monitor and report on the company's risk management, more effective in helping enterprises to implement internal management strategy,improve the risk management process, to achieve the purpose of internal audit for enterprises.

\subsection{Rich main business projects}

E - commerce enterprises in the development of competitive industries, it is recommended that ecommerce enterprises should join digital media enterprises and entertainment enterprises, developing of the advantages of industry, so as to achieve the purpose of reducing the main business of a single risk.

\subsection{Establish a credit rating system}

The existence of credit recovery risks is due to non-credit customers, share credit blacklists with ecommerce companies and financial institutions, establish a systematic credit blacklist information network, refused to low credibility of customers in the electricity business enterprises and financial institutions to consume, so that the e-commerce industry health operation.

\section{Author:}

Feng Yahong (1973-), female, Xi'an University of Science and Technology, Shaanxi Qishan people, Dr., associate professor, mainly engaged in financial risk management research and teaching work. No.58, Yanta Road, Beilin District, Xi'an, Shaanxi, China E-mail: 2437578442@qq.com. Tel: 13720753033; (Shaanxi, Xi'an, 710054).

Cao Feng (1992.10 -), female, Xi'an University of Science and Technology, Henan Zhumadian people, graduate students, the main research direction for financial risk management. E-mail: 67567807@qq.com. Tel: 15539660390; (Shaanxi, Xi'an, 710054)

\section{Acknowledgment}

Fund Project: Xi'an University of Science and Technology Philosophy and Social Sciences Prosperity Development Plan Key Project (2016SZ01), Moderator: Feng Yahong.

\section{References}

[1] Pourhosseini P. The relationship of financial incentives and consumers' willingness to disclose information to ecommerce marketers [M]. Walden University, 2009.

[2] Gai P, Kapadia S. Contagion in financial networks [J]. Proceedings Mathematical Physical \& Engineering Sciences, 2010, 466(2120):2401-2423.

[3] Feng Gaofei. Strategic alliance under the background of electricity business enterprise financial risk identification [J]. Finance and Accounting, 2016 (32).

[4] Xu Yufang. Internet business M \& A financial risk analysis [J]. Finance and Accounting, 2017 (17). 
[5] Palepu K G, Healy P M. Business analysis \& valuation: using financial statements [M]. SouthWestern College Pub, 1998. 